\title{
Summary of palaeomagnetic results from West Antarctica: implications for the tectonic evolution of the Pacific margin of Gondwana during the Mesozoic
}

\author{
VIC DIVENERE, ${ }^{1}$ DENNIS V. KENT ${ }^{1} \&$ IAN W. D. DALZIEL ${ }^{2}$ \\ ${ }^{1}$ Lamont-Doherty Earth Observatory and Department of Geological Sciences of \\ Columbia University Palisades, NY 10964, USA \\ ${ }^{2}$ Institute for Geophysics, University of Texas at Austin \\ 8701 Mopac Blvd, Austin, Texas 78759-8345, USA
}

\begin{abstract}
Marie Byrd Land (MBL) is the western keystone of West Antarctica. Recent palaeomagnetic results from Lower Cretaceous (c.117 Ma) plutonic and volcanic rocks from MBL in conjunction with a previous palaeomagnetic result from New Zealand suggest that eastern MBL and the Eastern Province of New Zealand originated in a position adjacent to Weddellia (Antarctic Peninsula, Thurston Island, and Ellsworth-Whitmore Mountains blocks) as part of a continuous Pacific convergent margin. This is far from their previously assumed position adjacent to the Western Province of New Zealand and North Victoria Land. The $117 \mathrm{Ma}$ palaeomagnetic pole for eastern MBL constrains the last movements of the Weddellia blocks related to spreading in the Weddell Sea to postdate the initial opening phase of the Weddell Sea. A c. $100 \mathrm{Ma}$ pole for the amalgamated mid-Cretaceous MBL is consistent with like age poles from the Thurston Island and Antarctic Peninsula blocks but all are significantly offset from a newly constructed apparent polar wander path for East Antarctica. From this it is concluded that there has been palaeomagnetically resolvable post-100 Ma motion between East Antarctica and the Pacific-bordering blocks of West Antarctica as a result of extension in the Ross Sea, Ross embayment, and Byrd Subglacial Basin.
\end{abstract}

West Antarctica is composed of four major crustal blocks: Marie Byrd Land (MBL), Thurston Island (TI), Antarctic Peninsula (AP), and Ellsworth-Whitmore Mountains (EWM) (Dalziel \& Elliott 1982) (Fig. 1). New Zealand was also part of West Antarctica before it separated from MBL at around $85 \mathrm{Ma}$ (Weissel et al. 1977; Grindley \& Davey 1982; Mayes et al. 1990). It has long been clear from Gondwana reconstructions (e.g., Smith \& Hallam 1970; Dietz \& Holden 1970; Norton \& Sclater 1979) that West Antarctica (or at least AP) must have experienced significant displacements with respect to East Antarctica following the separation of East from West Gondwana. This is because AP cannot be maintained in its current position with respect to East Antarctica in the reconstructions without serious overlap with South America and the Falkland Plateau. The similarity of the stratigraphy of the Ellsworth Mountains to the Transantarctic Mountains and the Cape Mountains of South Africa, and the isolated position and truncated structures of the
Ellsworth Mountains provided additional evidence for such displacements (Schopf 1969).

Much effort has been concentrated on understanding the evolution of West Antarctica following Gondwana break-up. Palaeomagnetic results from AP, TI, and EWM suggested that these three blocks constituted a tectonic entity termed 'Weddellia' (Grunow et al. 1987b) that was displaced more or less as a unit as a result of the opening of the Weddell Sea. Recent studies (Grunow et al. 1991; Grunow 1993) suggest more complicated (though not large), independent motions of these blocks. Nevertheless, Weddellia still seems an appropriate concept for the period of Gondwana break-up extending through the Early Cretaceous because the West Antarctic crustal motions during this period appear to be related to spreading in the Rocas Verdes-Weddell Sea basin (Barker et al. 1991; Dalziel 1992).

Previous studies have left several outstanding problems. Significant motions of Weddellia implied by palaeomagnetic studies postdate the 


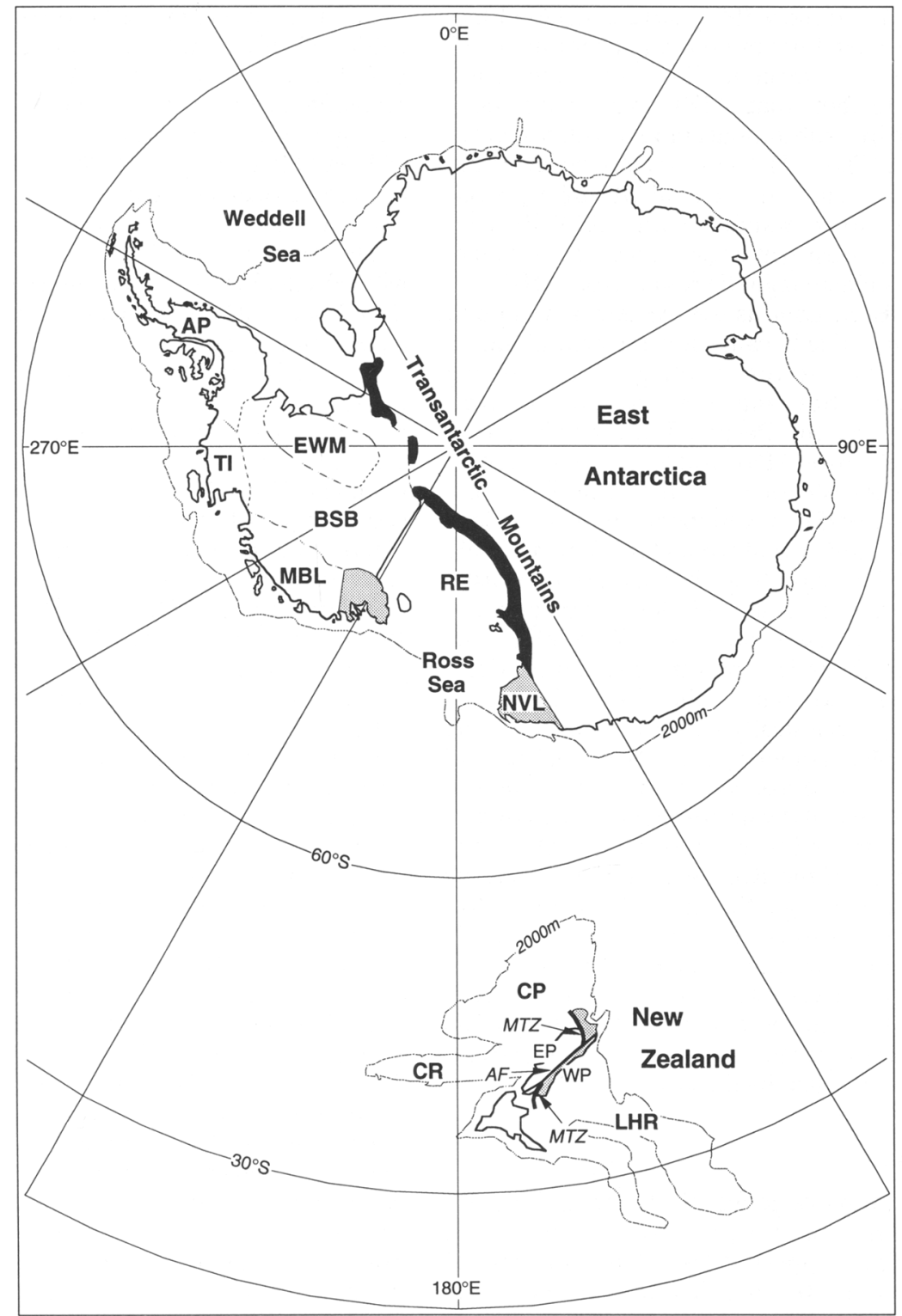

Fig. 1. Map of Antarctica and New Zealand showing Marie Byrd Land (MBL), Thurston Island (TI), Antarctic Peninsula (AP), and Ellsworth-Whitmore Mountains (EWM) crustal blocks of West Antarctica; Byrd Subglacial Basin (BSB) sensu lato, the entire area between MBL, TI, EWM, and the Transantarctic Mountains; Ross embayment (RE); North Victoria Land (NVL); the Eastern (EP) and Western (WP) provinces of New Zealand; Campbell Plateau (CP), Chatham Rise (CR), Lord Howe Rise (LHR), Median Tectonic Zone (MTZ; heavy black line), and the Alpine Fault (AF; medium black line). Stippled areas show areas of related lower Palaeozoic turbidites and Devonian granodiorites.

original opening of the Weddell Sea as interpreted from geophysical data in the Weddell Sea (LaBrecque \& Barker 1981; LaBrecque 1986). Also, relatively little palaeomagnetic work has been focused on MBL and New Zealand and hence no clear relationship has been established between these blocks and AP, TI, and EWM prior to or in conjunction with these motions of Weddellia. Finally, previous palaeomagnetic comparisons (Grindley \& Oliver 1983; Grunow 
et al. 1991; Grunow 1993) have concluded that there has been little or no relative motion of AP and TI with respect to East Antarctica since about 110 but that MBL may have been displaced by a substantial amount with respect to all three. These last conclusions were made, however, without the availability of a precise apparent polar wander path (APWP) constructed for East Antarctica and confirmation of the early palaeomagnetic results from MBL.

Marie Byrd Land is the western keystone of West Antarctica because it is the crucial link in the Ross Sea sector, relating motion among West Antarctica and East Antarctica, New Zealand, and the Pacific. Recent palaeomagnetic results from MBL and a newly constructed reference APWP for East Antarctica (DiVenere et al. 1994, 1995), in conjunction with a previous palaeomagnetic result from New Zealand, yield new insights regarding West Antarctic crustal motions. These results link the eastern portions of MBL and New Zealand with Weddellia since the Early Jurassic, confirm that major Early Cretaceous motions of the Weddellia blocks postdate geophysically based estimates for the time of original opening of the Weddell Sea, and reveal that there has been significant motion of MBL, TI, and AP with respect to East Antarctica since the mid-Cretaceous associated with the opening of the Ross Sea. In this paper, we review palaeomagnetic results from West Antarctica, the construction of the East Antarctic APWP, and our recent palaeomagnetic results from MBL. Reconstructions from our recent papers (DiVenere et al. 1994, 1995) highlight the interpretation of the tectonic evolution of West Antarctica implied by these new data.

\section{Problems}

Interpretations of geophysical data in the Weddell Sea and palaeomagnetic data from AP, TI, and EWM support West Antarctic crustal displacements, but the detailed history of the opening of the Weddell Sea and the associated West Antarctic crustal motions is far from clear. Estimated ages for the oldest oceanic magnetic anomalies of around 160 to $156 \mathrm{Ma}$ (M29 to M25; LaBrecque \& Barker 1981; LaBrecque 1986) and northeast-trending linear gravity anomalies in the southern Weddell Sea (Bell et al. 1990) suggest that rotations of the Weddellia blocks should predate the Early Cretaceous age implied by palaeomagnetic data (e.g., Grunow et al. 1991). However, the interpretation of the incomplete marine geophysical data in the Weddell Sea is as yet uncertain and Martin \& Hartnady (1986) indirectly inferred the initi- ation of spreading in the Weddell Sea as about $130 \mathrm{Ma}$ (M10) from the spreading history in the SW Indian Ocean. Nevertheless, ophiolitic remnants of the Rocas Verdes basin on South Georgia Island have been dated at close to $150 \mathrm{Ma}$ (Mukasa et al. 1988), showing that at least some oceanic crust was in existence in the region by the end of the Jurassic.

The relationship of MBL and New Zealand with Weddellia is poorly understood. Marie Byrd Land and New Zealand are normally left in a position adjacent to the Transantarctic Mountains and North Victoria Land in reconstructions. This is because lower Palaeozoic turbidites and Devonian granodiorites in western MBL, the Western Province of New Zealand, and North Victoria Land imply that MBL and New Zealand had been adjacent to North Victoria Land since these terranes were apparently sutured to East Antarctica in the late Palaeozoic (Borg \& DePaolo 1991; Weaver et al. 1991). Until recently there have been no reliable palaeomagnetic results from $\mathrm{MBL}$ older than mid-Cretaceous to test the original position of MBL. This has created the impression that MBL and the New Zealand microcontinent have evolved separately from Weddellia, even though the Eastern Province of New Zealand appears to have been part of a continuous Gondwana convergent margin (arc, forearc, and accretionary prism) extending from Chile through the Antarctic Peninsula to New Zealand during the Permian to Early Cretaceous (Dalziel \& Grunow 1985; Dalziel \& Forsythe 1985; Bradshaw 1989; Tranter 1991). Dalziel (1992) and Dalziel \& Grunow (1992), for example, separated Weddellia from MBL and New Zealand by a major transform fault.

The opening of the Weddell Sea was related to the earlier stages of Gondwana break-up with the separation (during the Mid-Jurassic) of Africa and South America (West Gondwana) from the rest of Gondwana (Barker et al. 1991; Royer \& Coffin 1992). Break-up continued around the margin of the present East Antarctic craton with the separation of India in the Early Cretaceous (Royer \& Coffin 1992) and eventually in the Ross Sea region as Australia separated and New Zealand rifted and separated in the mid- to Late Cretaceous (Weissel et al. 1977; Cande \& Mutter 1982; Royer \& Sandwell 1989). Cretaceous and Cenozoic extension in the Ross Sea and between East and West Antarctica has often been discussed but there has been much disagreement regarding the timing and amount of the motions. The suggestion, based on an interpretation of palaeomagnetic data (Grunow et al. 1991; Grunow 1993), that Weddellia and 
East Antarctica have been stationary with respect to one another since about $110 \mathrm{Ma}$ seems to contradict growing evidence that the Ross Sea, Ross embayment, and low-lying areas beneath the West Antarctic ice streams have been tectonically active during and since the Late Cretaceous and are still active (Behrendt \& Cooper 1991; Cooper et al. 1991; Storey 1991; Fitzgerald 1992; Stump \& Fitzgerald 1992; Blankenship et al. 1993; Behrendt et al. 1994). The palaeomagnetic poles from TI and AP have not been compared with a definitive APWP for East Antarctica. For example, the palaeomagnetic pole from the Lupata lavas of Africa (Gough \& Opdyke 1963) is often included in pole lists but with the caveat that secular variation was probably not averaged and the pole therefore likely to be biased, as noted by the authors (see also treatment in Hargraves 1989). This pole, transferred to East Antarctica, was used by Grunow (1993) as the sole c. $110 \mathrm{Ma}$ East Antarctic reference pole for comparison with AP and TI poles of similar age and formed one of the primary bases for concluding that there had been little or no post-110 Ma motion between AP/TI and East Antarctica. Advances in the quality of the global palaeomagnetic data base and plate kinematic models allow improvement of the East Antarctic APWP and reevaluation of post- $110 \mathrm{Ma}$ motion.

\section{East Antarctic APWP.}

Because only one palaeomagnetic reference pole (Mid-Jurassic) is available from East Antarctica for the Mesozoic and Cenozoic, it is necessary to transfer poles from other continents to evaluate tectonic motions of the West Antarctic crustal blocks with respect to East Antarctica for the remainder of this time. A new synthetic APWP was recently constructed for East Antarctica by transferring the most up to date and critically reviewed Cretaceous palaeomagnetic poles from Africa, North America, Australia, and India to East Antarctica using recent plate kinematic models (DiVenere et al. 1994). The individual Cretaceous poles in East Antarctic coordinates lie in a tight north-tosouth swath through the western Ross Sea. The mean reference poles fall in the western Ross Sea adjacent to North Victoria Land in the Early Cretaceous, to the south of Ross Island at about $100 \mathrm{Ma}$, and pass by the geographic south pole on the Indian Ocean side by about $90 \mathrm{Ma}$. The Cretaceous APWP for East Antarctica is similar to the Besse \& Courtillot (1991) APWP constructed from palaeomagnetic poles from the
Atlantic-bordering continents (see DiVenere et al. 1994).

The Mid- Jurassic pole for East Antarctica is well defined by numerous palaeomagnetic studies of the Ferrar dolerites and Kirkpatrick basalts (Kellogg 1988). Poles for earlier times were selected from the palaeomagnetic database for Gondwana of Van der Voo (1993). There are relatively few high-quality poles in the global data set for the time between about 175 and 130 $\mathrm{Ma}$, and there are contrasting interpretations of the poles that are available (Van Fossen \& Kent 1990, 1992, 1993; Butler et al. 1992). This controversial period (Van der Voo, 1992; Courtillot et al. 1994) is omitted from the East Antarctic APWP. The relevant reference poles for East Antarctic are listed in Table 1.

\section{West Antarctic palaeomagnetic results}

\section{Ellsworth-Whitmore Mountains}

The only palaeomagnetic poles from EWM are of Cambrian and $175 \mathrm{Ma}$ (Mid-Jurassic) age (Watts \& Bramall 1981; Grunow et al. 1987a; Table 1). Comparing these poles with reference poles from East Antarctica, Grunow et al. (1987a) concluded that EWM rotated about $90^{\circ}$ counterclockwise with respect to East Antarctica between the Cambrian and Mid-Jurassic, i.e., during a period of tectonic activity preceding the main opening of the Weddell Sea, and subsequently experienced a smaller but significant net clockwise rotation and poleward translation. There are no younger rocks exposed in EWM.

\section{Thurston Island}

Grunow et al. $(1987 b, 1991)$ reported palaeomagnetic results for $T I$ from rocks ranging in age from about 230 to $90 \mathrm{Ma}$. Based on a comparison of the two mid-Cretaceous (110 and $90 \mathrm{Ma}$ ) poles with selected poles from other Gondwana continents as proxies for East Antarctic reference poles, it was suggested that TI was at or near its present-day position with respect to East Antarctica by the mid-Cretaceous. However, the pre-110 Ma results were all found to be displaced from the reference poles in a sequence suggesting that TI had experienced a large clockwise followed by counterclockwise rotation with respect to East Antarctica during the Jurassic and Early Cretaceous.

\section{Antarctic Peninsula}

A number of palaeomagnetic results exist from AP ranging in age from Mid-Jurassic to Ceno- 
Table 1. Palaeomagnetic poles

\begin{tabular}{|c|c|c|c|c|c|c|}
\hline Block & Age & $N$ & $\mathrm{~A}_{95}$ & $\operatorname{Lon}^{\circ} \mathrm{E}$ & Lat $^{\circ} \mathrm{N}$ & Source \\
\hline MBL & 117 & 6 & 8.7 & 185.6 & -56.8 & DiVenere et al. (1995) \\
\hline MBL & 100 & 19 & 3.8 & 224.1 & -75.7 & DiVenere et al. (1994) \\
\hline$T I$ & 150 & 5 & 7 & 145 & -64 & Grunow et al. (1991) \\
\hline TI & 125 & 5 & 7.9 & 232 & -49 & Grunow et al. (1987a) \\
\hline TI & 110 & 7 & 7.6 & 210 & -73 & Grunow et al. (1991) \\
\hline AP & 175 & $4^{a}$ & 9.5 & 238 & -48 & Longshaw \& Griffiths (1983) \\
\hline$A P$ & 160 & 10 & 7.1 & 124 & -64 & Grunow (1993) \\
\hline$A P$ & 140 & 4 & 9.5 & 50 & -60 & Grunow (1993) \\
\hline$A P$ & 130 & 6 & 5.9 & 182 & -74 & Grunow (1993) \\
\hline AP & $106 \mathrm{M}$ & 29 & 6.2 & 203.8 & -74.3 & $\begin{array}{l}\text { calculated in DiVenere } \text { et al. (1994) } \\
\text { from site means of Kellogg (1980), } \\
\text { Kellog \& Rowley (1989), and Grunow } \\
\text { (1993) }\end{array}$ \\
\hline$E M W$ & Cambrian & 5 & $11.2^{\mathrm{b}}$ & 296 & 4 & Watts \& Bramall (1981) \\
\hline EWM & 175 & 8 & 5.3 & 235.2 & -41.2 & Grunow et al. $(1987 b)$ \\
\hline NZ & 207 & 24 & $10.6^{b}$ & 162 & -24 & $\begin{array}{l}\text { Grindley et al. (1981) with updated age } \\
\text { from Graham et al. (1993) }\end{array}$ \\
\hline EAnt & Tru/JI (206) & $4^{\mathrm{c}}$ & 7.0 & 242.4 & -58.0 & Van der Voo $(1993)^{\mathrm{d}, \mathrm{e}}$ \\
\hline EAnt & JI (186) & $3^{\mathrm{c}}$ & 11.0 & 225.3 & -54.3 & Van der Voo $(1993)^{\mathrm{f}, \mathrm{e}}$ \\
\hline EAnt & 175 & $17^{\mathrm{g}}$ & 4.4 & 220.4 & -52.7 & Kellogg (1988) \\
\hline EAnt & 125 & $6^{\mathrm{g}}$ & 3.5 & 173.9 & -71.9 & DiVenere et al. (1994) \\
\hline EAnt & 117 & $4^{\mathrm{g}}$ & 2.9 & 179.2 & -74.9 & DiVenere et al. (1994) \\
\hline EAnt & 102 & $6^{\mathrm{g}}$ & 4.2 & 171.8 & -80.3 & DiVenere et al. (1994) \\
\hline
\end{tabular}

MBL, Marie Byrd Land; TI, Thurston Island; AP, Antarctic Peninsula; FWM, Ellsworth-Whitmore Mountains; EAnt, East Antarctica; NZ, New Zealand; Lon and Lat are mean palaeomagnetic pole east longitude and north latitude (negative is south latitude); $\mathrm{N}$ is number of sites used to calculate mean; $\mathrm{A}_{95}$ is the radius of the $95 \%$ cone of confidence about the mean pole; poles listed in italics were not used in reconstructions.

a $N=4$ group means from 24 site means.

b A $_{95}$ conversatively estimated as the major axis of the confidence ellipse.

c $N=$ number of continent mean poles.

d Tru/JI mean pole, $230 \mathrm{E} / 70 \mathrm{~N}$ in northwest African coordinates.

e Gondwana mean poles rotated to East Antarctic reference frame using Euler pole consistent with Van der Voo (1993) plate model $(-12.36 /-33.81 /-53.29)$.

f JI mean pole, $260 \mathrm{E} / 70 \mathrm{~N}$ in northwest African coordinates.

$\mathrm{g} N=$ number of studies.

zoic. The Mid-Jurassic (c. 175 Ma) pole (Longshaw \& Griffiths 1983; Table 1) is not significantly different from the 175 Ma pole for EWM, while both poles are offset from the $175 \mathrm{Ma}$ reference pole for East Antarctica. This suggests that AP and EWM have experienced a similar post-175 Ma motion history (Grunow et al. $1987 a, b)$. Several palaeomagnetic studies of mid-Cretaceous (c. 110-90 Ma) rocks (Kellogg \& Reynolds 1978; Valencio et al. 1979; Watts et al. 1984; Kellogg \& Rowley 1989; Grunow 1993) give somewhat conflicting results. Combining the most recent data from the southern AP (Kellogg \& Rowley 1989) and northern AP (Grunow 1993) yields a c. $106 \mathrm{Ma}$ mean pole (DiVenere et al. 1994; Table 1) that is consistent with the $110 \mathrm{Ma}$ pole from TI (Grunow et al. 1991). For the period between 175 and about $110 \mathrm{Ma}$, Grunow (1993) reported results from Upper Jurassic/Lower Cretaceous rocks that are discordant, and results from Lower Cretaceous rocks that are concordant with the East Antarctic APWP. Accepting the AP poles at face value, it was concluded that AP had experienced a large clockwise rotation between about 175 and $160 \mathrm{Ma}$, a large counterclockwise rotation between about 160 and $130 \mathrm{Ma}$, and no significant motion with respect to East Antarctica since then (Grunow 1993).

\section{Marie Byrd Land}

During the tripartite United States-United Kingdom-New Zealand 1990-1991 South Pacific Rim International Tectonics Expedition (SPRITE) to Marie Byrd Land, oriented samples were collected for palaeomagnetic analysis. Two major portions of the collection are from Lower Cretaceous (c. $117 \mathrm{Ma}$ ) volcanic rocks and granodiorite, and mid-Cretaceous 
(c. $100 \mathrm{Ma}$ ) alkali syenites, granites, and gabbro (Weaver et al. 1994). Unpublished $\mathrm{Rb}-\mathrm{Sr}$ data have given $c .110-120 \mathrm{Ma}$ ages for the volcanic units and $118 \pm 2 \mathrm{Ma}$ for the granodiorite suite (R. J. Pankhurst pers. comm. 1993). Unpublished zircon $\mathrm{U}-\mathrm{Pb}$ data also give an age of about $117 \mathrm{Ma}$ for the granodiorite at Mount Steinfeld (S. B. Mukasa pers. comm. 1993). The mid-Cretaceous units have all yielded Rb-Sr (R. J. Pankhurst pers. comm. 1993) and zircon U-Pb and ${ }^{40} \mathrm{Ar}{ }^{39} \mathrm{Ar}$ (Palais et al. 1993; D. G. Palais \& S. B. Mukasa pers. comm. 1993) dates of around $100 \mathrm{Ma}$. The $100 \mathrm{Ma}$ rocks intrude the $117 \mathrm{Ma}$ rocks across the Ruppert/ Hobbs Coast. The Early and mid-Cretaceous poles from this study (DiVenere et al. 1994, 1995) supersede previous results of Scharnberger \& Scharon (1972) and Grindley \& Oliver (1983).

Although most of the Lower Cretaceous volcanic rocks collected have been thermally metamorphosed and remagnetized, palaeomagnetic results from six sites at Mount Vance in bedded, albeit hydrothermally altered, volcanic rocks are similar after tilt correction to results from a homogeneous $c .117$ Ma granodiorite at Mount Steinfeld. The volcanic rocks at Mount Vance have evidently not been remagnetized at a much later time and the results are supported by a positive contact test (confirming a pre$100 \mathrm{Ma}$ magnetization) and an indirect regional tilt (i.e., palaeohorizontal) test. The mean pole from the unremagnetized volcanic rocks (Table 1) is offset from the East Antarctic APWP, implying a clockwise rotation and southward translation between 117 and $100 \mathrm{Ma}$ (DiVenere et al. 1995). This result is similar to the c. $125 \mathrm{Ma}$ pole from TI (Grunow et al. 1991; Table 1) in that both call for Early Cretaceous clockwise rotations, suggesting that MBL and TI shared a common tectonic history.

Palaeomagnetic results from mid-Cretaceous alkali syenites and gabbro from 19 sites at six locations on the Ruppert/Hobbs Coast yield a c. $100 \mathrm{Ma}$ mean pole that is supported by a regional tilt test and agreement across a wide area (approximately $300 \mathrm{~km}$ ) of MBL (DiVenere et al. 1994; Table 1). This pole is consistent with the c. 110 and $106 \mathrm{Ma}$ poles from TI and AP respectively (Table 1 ), from which it may be concluded that MBL has not experienced significant post-100 Ma motion with respect to AP and TI. The West Antarctic poles, however, are all significantly $(95 \%$ confidence level) offset from the new East Antarctic reference APWP (DiVenere et al. 1994) indicating that the Pacific-bordering blocks of West Antarctica have in fact been displaced with respect to East Antarctica since the midCretaceous (DiVenere et al. 1994).

Samples were also collected during the 19921993 SPRITE field season from a granite in the Kohler Range of easternmost MBL (DiVenere 1993), previously dated by $\mathrm{K}-\mathrm{Ar}$ at about $100 \mathrm{Ma}$ (Wade \& Wilbanks 1972). These samples yielded stable palaeomagnetic results with a mean pole that is in excellent agreement with the $c .100$ Ma mean pole from the Ruppert/ Hobbs Coast. This extends the geographic baseline of mutually consistent mid-Cretaceous palaeomagnetic data to approximately $750 \mathrm{~km}$.

\section{Tectonic synthesis}

Adequate data now exist to propose the likely relationship of MBL and New Zealand with the Weddellia blocks. The new 117 Ma pole, which is based on results solely from east of $141^{\circ} \mathrm{W}$ (DiVenere et al. 1995), implies that MBL was far from North Victoria Land in the Early Cretaceous. This is contrary to the expected Early Cretaceous position of MBL adjacent to North Victoria Land based on the association of lower Palaeozoic turbidites and Devonian granodiorite found in western MBL, the western South Island of New Zealand, and the Robertson and Bowers Terranes of North Victoria Land (Fig. 1). These are thought to have comprised a terrane that accreted to the East Antarctic craton in the late Palaeozoic (Borg \& DePaolo 1991; Weaver et al. 1991). However, the critical rock units are only found to the west of about $141^{\circ} \mathrm{W}$ in MBL, and the relationship between MBL and North Victoria Land is therefore only likely for this part of MBL. We have therefore distinguished an 'East MBL' and 'West MBL' now joined approximately along $141^{\circ} \mathrm{W}$ longitude (DiVenere et al. 1995). Likewise in New Zealand, an assemblage of Palaeozoic rocks, correlative with those in West MBL and North Victoria Land, is only found in the Western Province, west of the Median Tectonic Zone (Bradshaw 1989; Kimbrough et al. 1993; Bradshaw 1993). In contrast, the Eastern Province of New Zealand is made up of Permian through Early Cretaceous arc, forearc, and accretionary complexes and mid-Cretaceous alkaline volcanic rocks (Bradshaw 1989; Weaver \& Pankhurst 1991). These are complementary with the Permian through Early Cretaceous calc-alkaline igneous rocks and mid-Cretaceous alkaline igneous rocks in East MBL. The relationship of the Eastern and Western Provinces of New Zealand across the Median Tectonic Zone is uncertain (Bradshaw 1993). The Eastern Province of New Zealand is made of a number of 


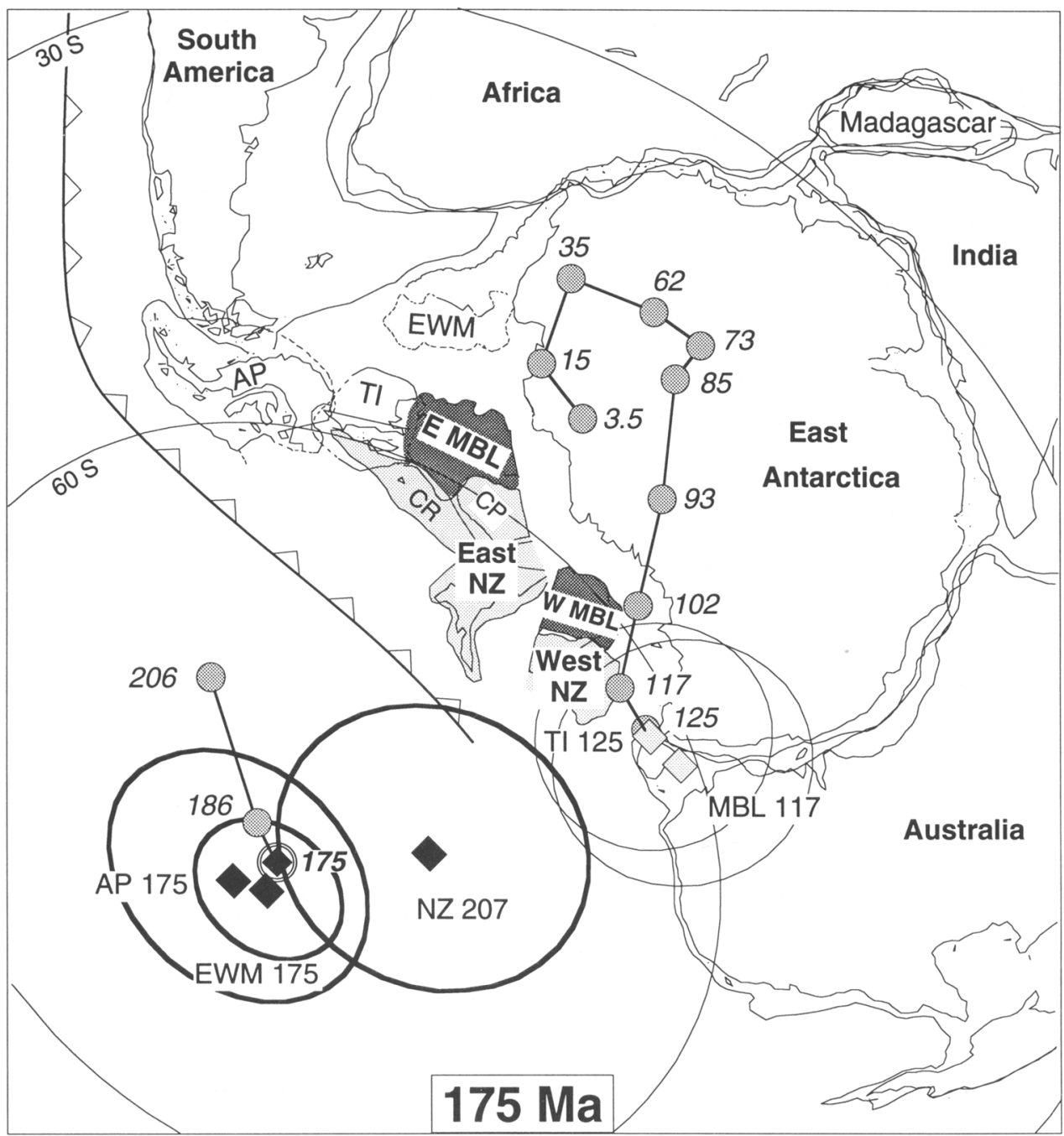

Fig. 2. Reconstruction of the West Antarctic and New Zealand crustal blocks within Gondwana for c. $175 \mathrm{Ma}$. Diamonds are palaeomagnetic poles from West Antarctic blocks and New Zealand with A95 circles of confidence shown in reconstructed positions. Connected grey circles are the East Antarctic APW path; Cretaceous to Cenozoic path is from DiVenere et al. (1994); 175 Ma pole is from Kellogg (1988); 186 and 206 Ma poles are Gondwana mean poles of Van der Voo (1993) transferred into the East Antarctic reference frame (DiVenere et al. 1995). Original poles are listed in Table 1. Crustal blocks: AP, Antarctic Peninsula; TI Thurston Island; EWM, Ellsworth-Whitmore Mountains; E MBL and W MBL, East and West Marie Byrd Land; NZ, East and West New Zealand; CR, Chatham Rise; CP, Campbell Plateau. East and West New Zealand are represented schematically since the position of the dividing line between them is uncertain.

terranes of uncertain relation (Bradshaw 1989) but we assume for the sake of simplicity in the reconstructions that Eastern Province was one integral crustal block. Given that the Eastern Province of New Zealand is known to have separated from MBL at about $85 \mathrm{Ma}$ (Mayes et al. 1990), it is a reasonable assumption that East MBL and the Eastern Province of New Zealand may have shared a common history prior to that.
Previous reconstructions that had maintained all of MBL and New Zealand in a position adjacent to North Victoria Land based on the Palaeozoic geologic relations leave a gap between the forearc sequences of New Zealand and AP (Dalziel 1992; Dalziel \& Grunow 1992). It is notable that if all of New Zealand is kept adjacent to North Victoria Land, then the earliest Jurassic palaeopole from the Murihiku 
Terrane of the Eastern Province of New Zealand (Grindley et al. 1981) does not agree with the East Antarctic APWP, as noted by Grindley et al. (1981). We have instead proposed that East MBL and the Eastern Province of New Zealand were originally part of the Weddellia province, while West MBL and the Western Province of New Zealand were adjacent to North Victoria Land (DiVenere et al. 1995). This allows for a better interpretation of the Murihiku pole.

A new series of reconstructions for c. 175, 117, and $100 \mathrm{Ma}$ that attempts to account for the palaeomagnetic data while maintaining reasonable geologic relationships has been presented by DiVenere et al. $(1994,1995)$. The major innovation in the Jurassic (175 Ma) and Early Cretaceous (117 $\mathrm{Ma})$ reconstructions is the recognition of separate eastern and western provinces in both MBL and New Zealand. The $100 \mathrm{Ma}$ reconstruction incorporates a tight fit in the Ross Sea region based on the now wellfounded post $100 \mathrm{Ma}$ extension in the Ross Sea.

The $175 \mathrm{Ma}$ reconstruction (Fig. 2) maintains the continuity of the Permian through Early Cretaceous arc, forearc, and accretionary complex rocks extending from the Eastern Province of New Zealand through AP and into southern South America and places the magmatic arc terranes (East MBL and TI) behind these. It also maintains the diorites, quartz diorites, and granodiorites of easternmost MBL, with $\mathrm{K}-\mathrm{Ar}$ (Lopatin et al. 1974) and Rb-Sr (Halpern 1972) ages ranging from 225 to $295 \mathrm{Ma}$, proximal to a gabbro-diorite suite on Thurston Island, with ages ranging from about 230 to $290 \mathrm{Ma}\left({ }^{40} \mathrm{Ar} /\right.$ ${ }^{39} \mathrm{Ar}, \mathrm{K}-\mathrm{Ar}$, and Rb-Sr; Pankhurst et al. 1993).

Dalziel \& Grunow (1992) proposed that the Ellsworth Mountains were displaced from a position between the Cape Fold Belt of South Africa and the Pensacola Mountains of East Antarctica in an early rifting episode between East and West Gondwana following PermoTriassic folding and prior to the Mid-Jurassic. The Falkland Islands also appear to have been displaced and rotated from a similar position at about the same time (Taylor \& Shaw 1989; Marshall 1994). The EWM block was rotated approximately $90^{\circ}$ counterclockwise and displaced towards its present position with respect to East Antarctica. We place EWM in a position similar to that of previous reconstructions in the Jurassic and Early Cretaceous (e.g., Grunow et al. 1991; Dalziel \& Grunow 1992), far from its present position with respect to East Antarctica. The palaeolatitude implied by the Mid-Jurassic pole for EWM combined with the reconstructed position implied by the Early Cretaceous pole for East MBL and the earliest Jurassic pole for the Eastern Province of New Zealand argue that EWM did not attain its current position with respect to East Antarctica until after about $117 \mathrm{Ma}$.

The Chatham Rise and Campbell Plateau of the Eastern Province of New Zealand are reconstructed to East MBL in their estimated midCretaceous, pre-separation position. With this configuration, the earliest Jurassic (c. 207 Ma) pole from the Eastern Province of New Zealand (Grindley et al. 1981) remains offset from the East Antarctic APW path, but now the position of the Eastern Province of New Zealand is consistent with the palaeolatitude implied by the pole. The remaining offset implies either that the Eastern Province of New Zealand and East MBL rotated as a unit with respect to East Antarctica between about 207 and $117 \mathrm{Ma}$ or that the Eastern Province of New Zealand (specifically, the Murihiku Terrane) rotated with respect to East MBL (and East Antarctica) between about 207 and $85 \mathrm{Ma}$.

It is interesting that this $175 \mathrm{Ma}$ configuration (Fig. 2) is able to satisfy the Early Cretaceous poles for MBL and TI as well as the Mid-Jurassic poles for AP and EWM with respect to the East Antarctic APWP. However, the arrangement must have evolved somewhat during the separation of East and West Gondwana and the early opening of the Weddell Sea. In particular, AP must have been displaced following East-West Gondwana separation and approached near to its present position with respect to East Antarctica by the mid-Cretaceous. In arriving at the 117 Ma reconstruction (Fig. 3), we suggest that AP had moved with South America as Africa and South America separated from East Antarctica. The early opening of the Weddell Sea can be regarded as a passive result of East-West Gondwana separation and linked with back arc-extension in the Rocas Verdes basin (Barker et al. 1991). The compatibility of the prebreakup and Early Cretaceous reconstructions (Figs 2 \& 3) offers a less complicated alternative to the large linked rotations of AP and TI proposed by Grunow (1993) for the intervening period.

Whether or not AP and TI experienced the Late Jurassic/Early Cretaceous rotations suggested by Grunow (1993), the new 117 Ma pole from MBL places the constraint that the Weddellia blocks did not attain their mid-Cretaceous positions until after about $117 \mathrm{Ma}$, postdating the initial opening of the Weddell Sea. The post-117 (and pre-100 Ma) motions would have occurred during the Cretaceous Long Normal interval (c. 118-84 Ma), during which time no lineated magnetic anomalies were produced to 


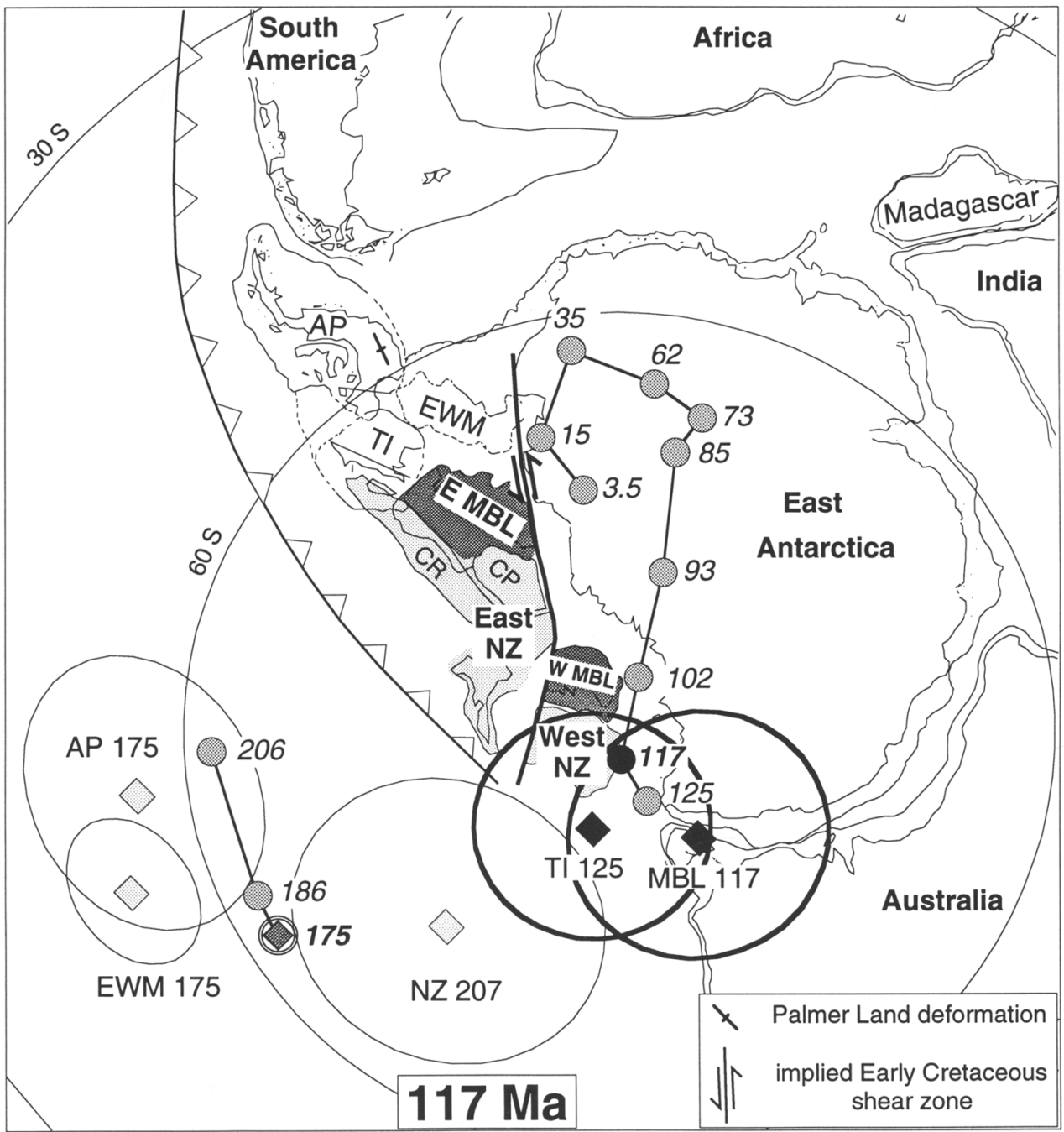

Fig. 3. Reconstruction of the West Antarctic and New Zealand crustal blocks within Gondwana for $c$. $117 \mathrm{Ma}$, with the Gondwana continents relative positions at magnetic anomaly M0 (DiVenere et al. 1995). Symbols as in Fig. 2.

serve as a record of motion in the Weddell Sea. However, Livermore \& Woollett (1993) propose a change in spreading direction in the Weddell Sea as deduced from a bend in gravity lineaments (presumably fracture zones) within the Cretaceous Quiet Zone.

The c. $100 \mathrm{Ma}$ mean palaeomagnetic pole from MBL, (produced from rocks from East MBL (DiVenere et al. 1994), implies that East MBL was at that time in a position nearer to the Transantarctic Mountains and North Victoria Land than it is at present. East and West MBL must therefore have been amalgamated by about $100 \mathrm{Ma}$. A formal statistical comparison of the c. $100 \mathrm{Ma}$ pole for MBL with the newly constructed East Antarctic APWP (which includes reconstruction-based error estimates for the mean poles) shows that there has been significant (i.e., palaeomagnetically discernible) post-100 Ma extension in the Ross Sea (DiVenere et al. 1994). Mid-Cretaceous poles from TI and AP are also significantly offset from the East Antarctic APWP implying that these blocks have also experienced some motion relative to East Antarctica since the midCretaceous. The c. $100 \mathrm{Ma}$ reconstruction (Fig. 4) shows about $50 \%$ post- 100 Ma extension in the Ross Sea, which is at the upper bound of 


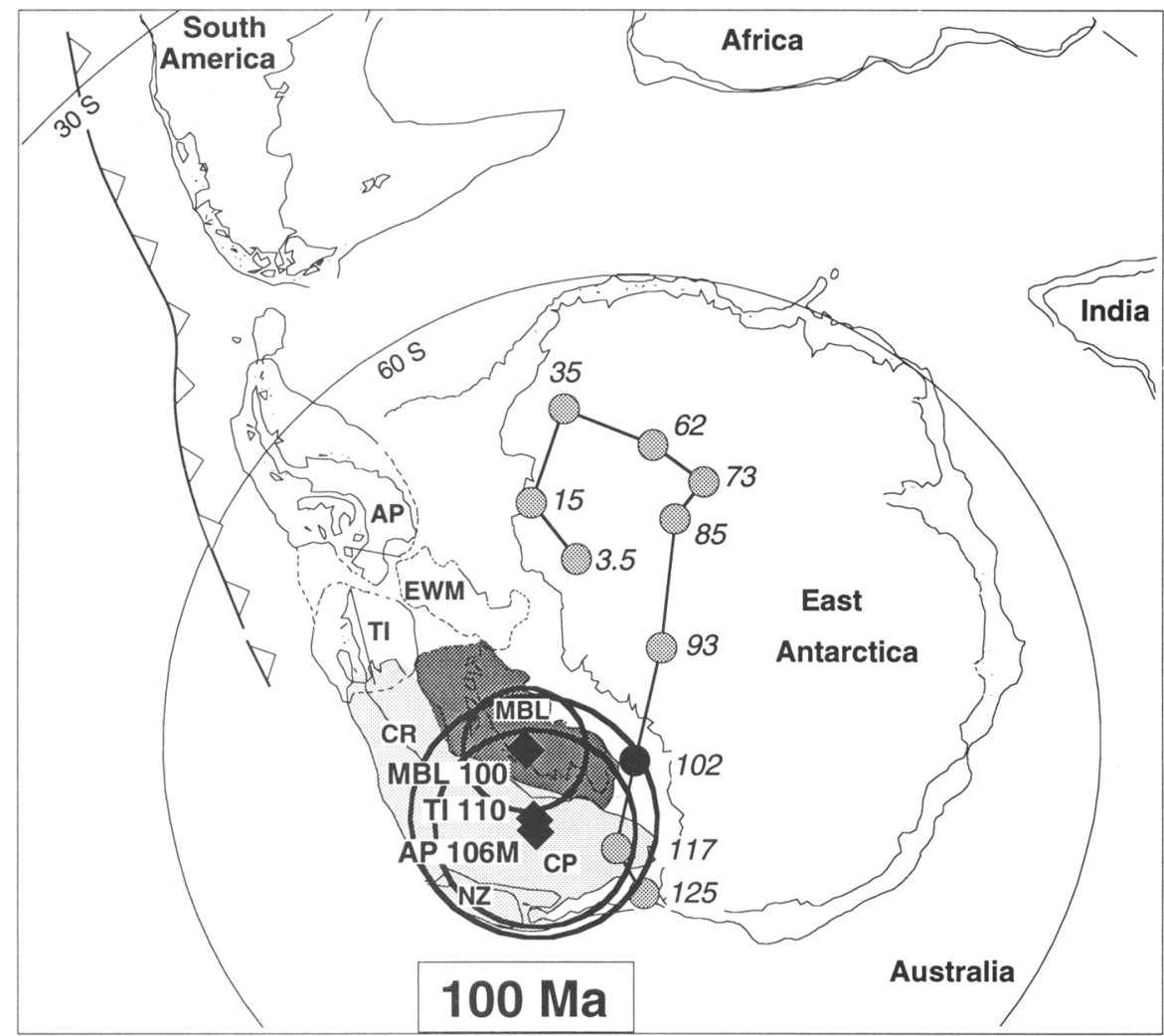

Fig. 4. Reconstruction of the West Antarctic and New Zealand crustal blocks within Gondwana for c. $100 \mathrm{Ma}$ (DiVenere et al. 1994). MBL and NZ, Marie Byrd Land and New Zealand, each as a whole. All other symbols as in Fig. 2.

the proposed geological estimates based on crustal thickness arguments (Behrendt \& Cooper 1991) and near the lower limit of the error bounds of the palaeomagnetic analysis (DiVenere et al. 1994). Given that the pole is from East MBL, it is possible that some of the total extension may be accounted for within West MBL.

Grunow (1993) related the Palmer Land deformation event in the southern AP, in which Middle and Upper Jurassic volcanic and sedimentary rocks were folded and thrusted prior to the emplacement of the Lassiter Coast intrusive suite between about 128 and $96 \mathrm{Ma}$ (Kellogg \& Rowley 1989; Pankhurst \& Rowley 1991), to the subduction of ocean crust first created and then destroyed by the proposed large clockwise and ensuing counterclockwise rotations of AP and TI in the Late Jurassic and Early Cretaceous. The Palmer Land event could also be explained in our model by collision with EWM (as previously suggested by Grunow et al. 1987a, 1991) or intervening crust as AP moved with South America followed by expulsion of EWM,
TI, and East MBL from the Weddell Sea sector in the Early Cretaceous.

The displacements of the Weddellia blocks eventually resulted in the suturing of East and West MBL and the Eastern and Western Provinces of New Zealand. We note that the timing of the implied displacements and suturing (between about 117 and $100 \mathrm{Ma}$ ) is approximately coeval with the last phase of the Rangitata II Orogeny in New Zealand (Bradshaw 1989). Though Bradshaw (1989) proposed that the Rangitata II deformation was caused by the approach and subduction of the Phoenix/Pacific Ridge, the MBL and New Zealand motions inferred from the palaeomagnetic results suggest that Eastern Province-Western Province amalgamation may have been at least partly responsible.

\section{Conclusions}

Early Cretaceous palaeomagnetic data from East MBL and a reassessment of the earliest 
Jurassic pole from New Zealand imply that East MBL and the Eastern Province of New Zealand were part of Weddellia from at least the Early Jurassic through the mid-Cretaceous. The Early Cretaceous pole from East MBL, in conjunction with the Early Cretaceous pole from TI, places the constraint that EWM, TI, East MBL, and the Eastern Province of NZ did not attain their mid-Cretaceous positions until after $117 \mathrm{Ma}$. This is after the estimated age of the initiation of spreading in the Weddell Sea. The post-117 Ma Weddellia block motions may therefore be the result of plate reorganization during the Cretaceous Long Normal interval rather than due to the initial opening of the Weddell Sea. The mid-Cretaceous poles from MBL, TI, and AP are all significantly offset from the East Antarctic APWP. From this we conclude that there has been palaeomagnetically resolvable displacement of the Pacific-bordering blocks of West Antarctica with respect to East Antarctica since about $100 \mathrm{Ma}$. This is compatible with geologic evidence for Cretaceous and Cenozoic extension in the Ross Sea, Ross embayment, and Byrd Subglacial Basin.

We would like to thank SPRITE members S. Mukasa and D. Palais of the University of Michigan, R. Pankhurst and B. Storey of the British Antarctic Survey (BAS), and J. Bradshaw and S. Weaver of the University of Canterbury for their contributions to this research and permission to use their unpublished data. We also thank mountaineers P. Cleary, A. Harris, and J.Roberts of the New Zealand Antarctic Research Program (NZARP; now NZAP) and D. Carroll of BAS for their expert guiding in the field and assistance in sample collection; Twin Otter pilots P. Robertson and L. Proudfoot and air mechanics A. Hopkins and S. Tucker of BAS for safely delivering us to distant outcrops; US Navy Antarctic Development Squadron VXE6 for LC-130 support; the US Office of Polar Programs and Antarctic Support Associates for logistical support; and NZARP and the personnel of Scott Base for field support and base accommodations. We thank L. Gahagan of the PLATES project at the Institute for Geophysics, University of Texas at Austin for help with the Antarctic reconstruction in Figs 2 and 4. This paper was improved with the help of thoughtful reviews by P. Barker, J. Bradshaw, and B. Storey. This research was supported by NSF Office of Polar Programs grants DPP 8916470 (D.V.K.) and DPP 8917127 (I.W.D.D.). Lamont-Doherty Earth Observatory contribution No.5379. University of Texas, Institute for Geophysics, contribution No. 1109.

\section{References}

Barker, P. F., Dalziel, I. W. D. \& Storey, B. C. 1991. Tectonic development of the Scotia Arc region. In: TingeY, R. J. (ed.) Antarctic Geology. Oxford University Press, 215-248.

Behrendt, J. C. \& Cooper, A. 1991. Evidence of rapid Cenozoic uplift of the shoulder escarpment of the Cenozoic West Antarctic rift system and a speculation on possible climate forcing. Geology, 19, 315-319.

- Blankenship, D. D., Finn, C. A., Bell, R. E., Sweeney, R. E., Hodge, S. M. \& Brozena, J. M. 1994. CASERTZ aeromagnetic data reveal late Cenozoic flood basalts(?) in the West Antarctic rift system. Geology, 22, 527-530.

Bell, R. E., Brozena, J. M., Haxby, W. F. \& LaBrecQue, J. L. 1990. Continental margins of the western Weddell Sea: insights from airborne gravity and geosat-derived gravity. In: Contributions to Antarctic Research I, Antarctic Research Series, 50, AGU, Washington, DC, 91-102.

Besse, J. \& Courtillot, V. 1991. Revised and synthetic apparent polar wander paths of the African, Eurasian, North American and Indian plates, and true polar wander since $200 \mathrm{Ma}$. Journal of Geophysical Research, 96, 4029-4050.

Blankenship, D. D., Bell, R. E., Hodge, S. M., Brozena, J. M., Behrendt, J. C. \& Finn, C. A. 1993. Active volcanism beneath the West Antarctic ice sheet and implications for ice-sheet stability. Nature, 361, 526-529.

Borg, S. G., \& DePaolo, D. J. 1991. A tectonic model of the Antarctic Gondwana margin with implications for southeastern Australia: isotopic and geochemical evidence. Tectonophysics, 196, 339-358.

Bradshaw, J. D. 1989. Cretaceous geotectonic patterns in the New Zealand region. Tectonics, 8, 803-820.

— 1993. A review of the Median Tectonic Zone: terrane boundaries and terrane amalgamation near the Median Tectonic Line. New Zealand Journal of Geology and Geophysics, 36, 117-125.

Butler, R. F., May, S. R. \& Bazard, D. R. 1992. Comment on 'High-latitude paleomagnetic poles from Middle Jurassic plutons and Moat volcanics in New England and the controversy regarding Jurassic apparent polar wander for North America' by M. C. Van Fossen \& D. V. Kent. Journal of Geophysical Research, 97, 1801-1802.

Cande, S. C. \& Mutter, J. C. 1982. A revised identification of the oldest sea-floor spreading anomalies between Australia and Antarctica. Earth and Planetary Science Letters, 58, 151-160.

Cooper, A. K., Davey, F. J. \& Hinz, K. 1991. Crustal extension and origin of sedimentary basins beneath the Ross Sea and Ross Ice Shelf, Antarctica. In: Thomson, M. R. A., Crame, J. A. \& Thomson, J. W. (eds) Geological Evolution of Antarctica. Cambridge University Press, New York, 285-291.

Courtillot, V., Besse, J. \& Théveniaut. 1994. North American Jurassic apparent polar wander: the answer from other continents? Physics of the Earth and Planetary Interiors, 82, 87-104.

Dalziel, I. W. D. 1992. Antarctica; A tale of two supercontinents? Annual Reviews of Earth and Planetary Science, 20, 501-526.

\& EilioT, D. H. 1982. West Antarctica: problem child of Gondwanaland. Tectonics, 1, 3-19. 
\& Forsythe, R. D. 1985. Andean evolution and the terrane concept. In: Howell, D. G. (ed.) Tectonostratigraphic Terranes of the CircumPacific Region. Circum-Pacific Council for Energy \& Mineral Resources, Earth Science Series, 1. Houston, 565-581.

— \& Grunow, A. M. 1985. The Pacific margin of Antarctica: terranes within terranes within terranes. In: Howell, D. G. (ed.) Tectonostratigraphic Terranes of the Circum-Pacific Region. Circum-Pacific Council for Energy \& Mineral Resources, Earth Science Series, 1. Houston, 555-564.

- \&-1992. Late Gondwanide tectonic rotations within Gondwanaland. Tectonics, 11, 603-606.

DieTz, R. S. \& Holden, J. C. 1970. Reconstruction of Pangaea: Breakup and dispersion of continents, Permian to present. Journal of Geophysical Research, 75, 4939-4956.

DiVenere, V. J. 1993. Mid Cretaceous paleomagnetic results from eastern Marie Byrd Land, West Antarctica: implications for relative motion between East and West Antarctica. Abstract, EOS, $74,115$.

—, Kent, D. V. \& Dalziel, I. W. D. 1994. Mid-Cretaceous paleomagnetic results from Marie Byrd Land, West Antarctica: a test of post-100 Ma relative motion between East and West Antarctica. Journal of Geophysical Research, 99, 15115-15139.

— \& - 1995. Early Cretaceous paleomagnetic results from Marie Byrd Land, West Antarctica: implications for the Weddellia collage of crustal blocks. Journal of Geophysical Research, 100, 8133-8152.

FitzGerald, P. G. 1992. The Transantarctic Mountains of Southern Victoria Land: The application of apatite fission track analysis to a rift shoulder uplift. Tectonics, 11, 634-662.

Gough, D. I. \& Opdyke, N. D. 1963. The paleomagnetism of the Lupata alkaline volcanics. Geophysical Journal of the Royal Astronomical Society, 7, 457-468.

Graham, I. J., Coombs, D. S. \& Cook, N. D. J. 1993. Effects of low-temperature alteration on the $\mathrm{Rb}-\mathrm{Sr}$ age of andesitic igneous rocks: Park Volcanics Group, Southland, New Zealand. Chemical Geology (Isotope Geoscience Section), 104, 281-292.

GrindLeY, G. W. \& DAVEY, F. J. 1982. The reconstruction of New Zealand, Australia, and Antarctica. In: CRADDOCK, C. (ed.) Antarctic Geoscience. University of Wisconsin Press, Madison, 15-29.

— \& Oliver, P. J. 1983. Paleomagnetism of Cretaceous volcanic rocks from Marie Byrd Land. In: Oliver, R. L., JAmes, P. R. \& JAGo, J. B. (eds) Antarctic Earth Science. Australian Academy of Science, Canberra, New South Wales, 573-578.

,$--\&$ Sukroo, J. C. 1981. Lower Mesozoic position of southern New Zealand determined from paleomagnetism of the Glenham Porphyry, Murihiku Terrane, Eastern Southland. In: CRESSWell, M. M. \& Vella, P. (eds) Gondwana Five. A. A. Balkema, Rotterdam, 319-326.

Grunow, A. M. 1993. Paleomagnetic data from the
Antarctic Peninsula and their implication for opening of the Weddell Sea. Journal of Geophysical Research, 98, 13815-13833.

—, DAlziel, I. W. D. \& Kent, D. V. $1987 a$. Ellsworth-Whitmore Mountains crustal block, western Antarctica: New paleomagnetic results and their tectonic significance. In: McKenzIE, G. D. (ed.) Gondwana Six: Structure, Tectonics and Geophysics. AGU, Geophysical Monograph Series. 40, 161-171.

,$--\&-1987 b$. Mesozoic evolution of West Antarctica and Weddell Sea Basin: new paleomagnetic constraints. Earth and Planetary Science Letters, 86, 16-26.

,$--\&-1991$. New paleomagnetic data from Thurston Island: implications for the tectonics of West Antarctica and Weddell Sea Opening. Journal of Geophysical Research, 96, 17935-17954.

HALPERN, M. 1972. Rb-Sr total-rock and mineral ages from the Marguerite Bay area, Kohler Range and Fosdick Mountains. In: AdIE, R. J. (ed.) Antarctic Geology and Geophysics. Universitetsforlaget, Oslo, 197-204.

Hargraves, R. B. 1989. Paleomagnetism of Mesozoic kimberlites in Southern Africa and the Cretaceous apparent polar wander curve for Africa. Journal of Geophysical Research, 94, 1851-1866.

KellogG, K. S. 1980. Paleomagnetic evidence for oroclinal bending of the southern Antarctic Peninsula. Geological Society of America Bulletin, 91, 414-420.

1988. A paleomagnetic investigation of rocks from the Ohio Range and the Dry Valleys, Transantarctic Mountains, Antarctica. New Zealand Journal of Geology and Geophysics, 31, 77-85.

— \& Reynolds, R. L. 1978. Paleomagnetic results from the Lassiter Coast, Antarctica, and a test for oroclinal bending of the Antarctic Peninsula. Journal of Geophysical Research, 83, 2293-2298.

_ \& Rowley, P. D. 1989. Structural geology and tectonics of the Orville Coast region, southern Antarctic Peninsula, Antarctica. US Geological Survey Professional Papers, 1498.

Kimbrough, D. L., Tulloch, A. J., Geary, E., Coombs, D. S. \& LANDIS, C. A. 1993. Isotopic ages from the Nelson region of South Island New Zealand: crustal structure and definition of the Median Tectonic Zone. Tectonophysics, 225, $433-448$

LaBrecque, J. L. 1986. South Atlantic Ocean and Adjacent Continental Margin. Atlas 13, Ocean Margin Drilling Program, Regional Atlas Series, 21 sheets. Woods Hole, Massachusetts; Marine Science International.

- \& BARKER, P. F. 1981. The age of the Weddell basin. Nature, 290, 489-492.

Livermore, R. A. \& Woollett, R. W. 1993. Seafloor spreading in the Weddell Sea and southwest Atlantic since the Late Cretaceous. Earth and Planetary Science Letters, 117, 475-495.

Longshaw, S. K. \& Griffiths, D. H. 1983. A palaeomagnetic study of Jurassic rocks from the Antarctic Peninsula and its implications. Journal of the Geological Society, London, 140, 945-954. 
Lopatin, B. G., Krylov, A. Y. \& Aliapyshev, O. A. 1974. Main tectonomagmatic stages of development of Marie Byrd Land and Eights Coast, West Antarctica according to radioactive data. Antarktika, 13, 52-61.

Marshall, J. E. A. 1994. The Falkland Islands: A key element in Gondwana paleogeography. Tectonics, 13, 499-514.

Martin, A. K. \& Hartnady, C. J. H. 1986. Plate tectonic development of the southwest Indian Ocean, a revised reconstruction of East Antarctica and Africa. Journal of Geophysical Research, 91, $476-486$.

Mayes, C., Sandwell, D. T. \& Lawver, L. A. 1990. Tectonic history and new isochron chart of the South Pacific. Journal of Geophysical Research, 95, 8543-8567.

Mukasa, S. B., Dalziel, I. W. D. \& Brueckner, H. K. 1988. Zircon U-Pb Constraints on the kinematic evolution of the northern Scotia Arc. Abstracts with Programs, GSA Annual Meeting, 20, A12.

Norton, I. O. \& Sclater, J. G. 1979. A model for the evolution of the Indian Ocean and the breakup of Gondwanaland. Journal of Geophysical Research, 84, 6803-6830.

Palais, D. G., Mukasa, S. B. \& Weaver, S. D. 1993. $\mathrm{U}-\mathrm{Pb}$ and ${ }^{40} \mathrm{Ar} /{ }^{39} \mathrm{Ar}$ geochronology for plutons along the Ruppert and Hobbs Coasts, Marie Byrd Land, West Antarctica: Evidence for rapid transition from arc to rift-related magmatism (abstract). EOS, 74(16), 123.

Pankhurst, R. J. \& Rowley, P. D. 1991. Rb-Sr study of Cretaceous plutons from southern Antarctic Peninsula and eastern Ellsworth Land, Antarctica. In: Thomson, M. R. A., Crame, J. A. \& Thomson, J. W. (eds), Geological Evolution of Antarctica. Cambridge University Press, 387-394.

-, Millar, I. L., Grunow, A. M. \& Storey, B. C. 1993. The Pre-Cenozoic magmatic history of the Thurston Island crustal block, West Antarctica. Journal of Geophysical Research, 98, 1183511849.

ROYER, J.-Y. \& COFFIN, M. F. 1992. Jurassic to Eocene plate tectonic reconstructions in the Kerguelen Plateau region. Ocean Drilling Program, 120, 917-928.

— \& Sandwell, D. T. 1989. Evolution of the Eastern Indian Ocean since the Late Cretaceous: constraints from Geosat altimetry. Journal of Geophysical Research, 94, 13755-13782.

Scharnberger, C. K. \& Scharon, L. 1972. Paleomagnetism and plate tectonics of Antarctica. In: Adie, R. J. (ed.) Antarctic Geology and Geophysics. Universitetsforlaget, Oslo, 843-847.

Schopf, J. M. 1969. Ellsworth Mountains: position in West Antarctica due to sea floor spreading. Science, 164, 63-66.

Smith, A. G. \& Hallam, A. 1970. The fit of the southern continents. Nature, 225, 139-144.

Storey, B. C. 1991. The crustal blocks of West Antarctica within Gondwana: reconstruction and break-up model. In: Thomson, M. R. A., Crame, J. A. \& Thomson, J. W. (eds) Geological Evolution of Antarctica. Cambridge University Press, New York. 587-592.
Stump, E. S. \& Fitzgerald, P. G. 1992. Episodic uplift of the Transantarctic Mountains. Geology, 20, 161-164.

TAYLOR, G. K. \& SHAw, J. 1989. The Falkland Islands: New palaeomagnetic data and their origin as a displaced terrane from southern Africa. In: HillHouse, J. W. (ed.) Deep Structure and Past Kinematics of Accreted Terranes. AGU, Geophysical Monograph Series, 50, 59-72.

Tranter, T. H. 1991. Accretion and subduction processes along the Pacific margin of Gondwana, central Alexander Island. In: Thomson, M. R. A., Crame, J. A. \& Thomson, J. W. (eds) Geological Evolution of Antarctica. Cambridge University Press, New York, 437-441.

Valencio, D. A., Mendîa, J. E. \& Vilas, J. F. 1979. Palaeomagnetism and $\mathrm{K}-\mathrm{Ar}$ age of Mesozoic and Cenozoic igneous rocks from Antarctica. Earth and Planetary Science Letters, 45, 61-68.

VAN DER VOo, R. 1992. Jurassic paleopole controversy: Contributions from the Atlanticbordering continents. Geology, 20, 975-978.

1993. Paleomagnetism of the Atlantic, Tethys and Iapetus Oceans. Cambridge University Press.

VAn Fossen, M. C. \& Kent, D. V. 1990. High latitude paleomagnetic poles from Middle Jurassic plutons and Moat Volcanics in New England and the controversy regarding Jurassic apparent polar wander for North America. Journal of Geophysical Research, 95, 17503-17516.

_ \& 1992. Reply to comment by Butler et al. Journal of Geophysical Research, 97, 1803-1805. \& _ 1993. A palaeomagnetic study of $143 \mathrm{Ma}$ kimberlite dikes in central New York State. Geophysical Journal International, 113, 175-185.

Watts, D. R., \& Bramall, A. M. 1981. Palaeomagnetic evidence for a displaced terrain in Western Antarctica. Nature, 293, 638-641.

—, Watts, G. C. \& Bramall, A. M. 1984. Cretaceous and Early Tertiary paleomagnetic results from the Antarctic Peninsula. Tectonics, 3, 333346.

Weaver, S. D. \& Pankhurst, R. J. 1991. A precise $\mathrm{Rb}-\mathrm{Sr}$ age for the Mandamus Igneous Complex, North Canterbury, and regional tectonic implications. New Zealand Journal of Geology and Geophysics, 34, 341-345.

_- Bradshaw, J. D. \& Adams, C. J. 1991. Granitoids of the Ford Ranges, Marie Byrd Land, Antarctica. In: Thomson, M. R. A., Crame, J. A. \& Thomson, J. W. (eds) Geological Evolution of Antarctica. Cambridge University Press, New York, 345-351.

-Storey, B. C., Pankhurst, R. J., Mukasa, S. B., DiVenere, V. J. \& Bradshaw, J. D. 1994. Antarctica-New Zealand rifting and Marie Byrd Land lithospheric magmatism linked to ridge subduction and mantle plume activity. Geology, 22, 811-814.

Weissel, J. K., Hayes, D. E. \& Herron, E. M. 1977. Plate tectonics synthesis: The displacements between Australia, New Zealand, and Antarctica since the Late Cretaceous. Marine Geology, 25, 231-277. 